\title{
Resurgence of Soilborne Pests in Double- cropped Cucumber after Application of Methyl Bromide Chemical Alternatives and Solarization in Tomato
}

\author{
James P. Gilreath ${ }^{1}$, Timothy N. Motis ${ }^{1}$, Bielinski M. Santos ${ }^{1}$, \\ Joseph W. Noling ${ }^{2}$, Salvadore J. Locascio ${ }^{3}$, and \\ Daniel O. Chellemi ${ }^{4}$
}

AdDitional INDEX WORDs. Cyperus, nutsedge, root-knot nematode, soil fumigant, 1,3-dichloropropene, pebulate, napropamide

SuMMARY. Field studies were conducted during four consecutive tomato (Lycopersicon esculentum) -cucumber (Cucumis sativus) rotations to examine the longterm residual effects of tomato methyl bromide $(\mathrm{MBr})$ alternatives on soilborne pests in double-cropped cucumber. Four treatments were established in tomato fields: a) nontreated control; b) $\mathrm{MBr}+$ chloropicrin (Pic) $(67: 33$ by weight) at a rate of $350 \mathrm{lb} /$ acre; c) tank-mixed pebulate + napropamide at 4 and $2 \mathrm{lb} /$ acre, respectively, followed by 1,3 -dichloropropene $(1,3-\mathrm{D})+\operatorname{Pic}(83: 17$ by volume $)$ at $40 \mathrm{gal} / \mathrm{acre}$; and d) napropamide at $2 \mathrm{lb} / \mathrm{acre}$ followed by soil solarization for 7 to 8 weeks. Each of the following seasons, cucumber was planted in the same tomato plots without removing mulch films. For nutsedge [purple nutsedge (Cyperus rotundus) and yellow nutsedge (C. esculentus)] densities, napropamide followed by solarization plots had equal control $\left(\leq 15\right.$ plants $\left./ \mathrm{m}^{2}\right)$ as $\mathrm{MBr}+\mathrm{Pic}$ during all four cropping seasons. However, nematode control with solarization was inconsistent. Marketable yield data proved that fumigation in tomato fields with either $\mathrm{MBr}+\mathrm{Pic}$ or pebulate + napropamide followed by $1,3-\mathrm{D}+\mathrm{Pic}$ had a long-term effect on double-cropped cucumber.

$\mathrm{T}$ he combination of $\mathrm{MBr}$ with Pic for soil fumigation has been the mainstay of the mulched vegetable production system in Florida since the 1970s (Overman and Martin, 1978). The loss of $\mathrm{MBr}$ as a soil fumigant (U.S. Evironmental Protection Agency, 1999) has resulted in considerable research for both chemical and nonchemical alternatives (Chase et al., 1997a, 1997b; Chellemi et al., 1997; Gilreath et al., 1994; Jones et al., 1995; Locascio et al., 1997). Among

Research paper approved as Florida Agricultural Experiment Station Journal Series R-10869. This project was supported by the Florida Tomato Committee, the USDA-Agricultural Research Service, the Florida Fruit and Vegetable Research and Education Foundation, and Taylor \& Fulton, Inc.

${ }^{1}$ Professor of Weed Science, Former Research Associate, and Horticultural Research Associate, Gulf Coast Research and Education Center, University of Florida, 14625 County Rd. 672, Wimauma, FL 33598; email: bmsantos@ifas.ufl.edu.

${ }^{2}$ Professor of Nematology, Citrus Research and Education Center, University of Florida, Lake Alfred, FL 33850

${ }^{3}$ Emeritus Professor, Horticultural Sciences Department, University of Florida, Gainesville, FL 32611.

${ }^{4}$ Research Plant Pathologist, ARS-United States Department of Agriculture, Ft. Pierce, FL 34945. the chemical alternatives, the efficacy of 1,3-D + Pic combined with the herbicide pebulate has been demonstrated as a potential replacement for $\mathrm{MBr}+\mathrm{Pic}$ in tomato production (Gilreath et al., 1994, 1997; Locascio et al., 1997). In most cases, this combination resulted in tomato yields similar to those achieved with $\mathrm{MBr}+\mathrm{Pic}$. Other herbicides, such as napropamide, have further improved weed control with fumigants (Gilreath et al., 2004).

Soil solarization has provided good yellow and purple nutsedge control when used in the summer months and it has been proposed as a nonchemical alternative to $\mathrm{MBr}$
(Chase et al., 1997a, 1997b; Chellemi et al., 1997). Soilborne pest control with solarization is accomplished by heating the soil prior to crop establishment. High soil temperatures lethal to soilborne pest propagules are obtained by covering the soil with transparent polyethylene film for 6 to 8 weeks. Chase et al. (1999) obtained $100 \%$ mortality of nutsedge tubers with soil temperatures between 50 and $55^{\circ} \mathrm{C}$.

Growers usually produce tomato in the same field during one season per year, while the following season the fields are either: a) disked and left to fallow; b) planted with a cover crop; or c) planted with a rotational crop, such as cucumber, by reusing the polyethylene-mulched beds. This latter practice, called double-cropping, utilizes the established beds and irrigation system, residual fertilizer, and effect from the soil fumigant. Scarce work has addressed the benefit of $\mathrm{MBr}$ alternatives to a double-crop. Gilreath et al. (2004) showed that double-cropped cucumber benefited from fumigant applications from previous bell pepper (Capsicum annumm) crops. However, the long-term effect of fumigant programs on successive crops has not been demonstrated. Therefore, the objective of this research was to examine the long-term residual effects of tomato $\mathrm{MBr}$ alternatives on soilborne pests in double-cropped cucumber.

\section{Materials and methods}

The experiment was conducted during four fall (1998 to 2001) and four spring (1999 to 2002) seasons at the Gulf Coast Research and Education Center in Bradenton, Fla., on an EauGallie fine sand soil with $98 \%$ sand, less than $2 \%$ silt, $0.8 \%$ organic matter, and a $\mathrm{pH}$ of 7.1. Treatments applied each year prior to a fall tomato crop consisted of: a) nontreated control; b) $\mathrm{MBr}+$ chloropicrin (Pic) $(67: 33$

\begin{tabular}{llll}
\hline $\begin{array}{l}\text { Units } \\
\text { To convert U.S. to SI, } \\
\text { multiply by }\end{array}$ & U.S. unit & SI unit & $\begin{array}{l}\text { To convert SI to U.S., } \\
\text { multiply by }\end{array}$ \\
\hline 29.5735 & $\mathrm{fl} \mathrm{oz}$ & $\mathrm{mL}$ & 0.0338 \\
0.3048 & $\mathrm{ft}$ & $\mathrm{m}$ & 3.2808 \\
0.0929 & $\mathrm{ft}^{2}$ & $\mathrm{~m}^{2}$ & 10.7639 \\
3.7854 & $\mathrm{gal}$ & $\mathrm{L}$ & 0.2642 \\
9.3540 & gal/acre & $\mathrm{L} \cdot \mathrm{ha}^{-1}$ & 0.1069 \\
2.5400 & inch(es) & $\mathrm{cm}$ & 0.3937 \\
16.3871 & inch & $\mathrm{cm} 3$ & 0.0610 \\
1.1209 & $\mathrm{lb} / \mathrm{acre}$ & $\mathrm{kg} \cdot \mathrm{ha}^{-1}$ & 0.8922 \\
0.0254 & mil & $\mathrm{mm}$ & 39.3701 \\
$\left({ }^{\circ} \mathrm{F}-32\right) \div 1.8$ & ${ }^{\circ} \mathrm{F}$ & ${ }^{\circ} \mathrm{C}$ & $\left(1.8 \times{ }^{\circ} \mathrm{C}\right)+32$
\end{tabular}


by weight) at a rate of $350 \mathrm{lb} /$ acre; c) tank-mixed pebulate + napropamide at 4 and $2 \mathrm{lb} /$ acre, respectively, followed by 1,3-dichloropropene (1,3-D) + Pic ( $83: 17$ by volume) at $40 \mathrm{gal} / \mathrm{acre}$; and d) napropamide at $2 \mathrm{lb} /$ acre followed by soil solarization for 7 to 8 weeks. During the spring season following each fall tomato crop, plots were double-cropped with cucumber utilizing the mulched beds.

Treatments each year were assigned to three-bed plots that were $60 \mathrm{ft}$ long, arranged in a randomized complete-block design, and replicated six times. Beds were 32 inches wide at the base, 28 inches wide at the top, 8 inches high, and spaced 60 inches apart on centers. Treatments were situated on the same plots each year to determine potential cumulative treatment effects over the duration of the experiment.

Starter fertilizer (N at $56 \mathrm{lb} / \mathrm{acre}$, $\mathrm{P}$ at $25 \mathrm{lb} / \mathrm{acre}$, and $\mathrm{K}$ at $47 \mathrm{lb} /$ acre) was broadcast and incorporated with an s-tine harrow just prior to bed formation for each treatment. Herbicides were applied broadcast with an 85 -gal spray solution and incorporated 5 inches deep with an s-tine harrow, 1 to $5 \mathrm{~d}$ prior to bed formation for each treatment. The 7 to 8 week solarization period began on 28 July 1998, 14 July 1999, 19 July 2000, and 1 Aug. 2001 when beds were formed and soil temperature reached a maximum average of $55{ }^{\circ} \mathrm{C}$. Drip irrigation tubing $[0.45 \mathrm{gal} / \mathrm{min}$ per $100 \mathrm{ft}$ of row, $1-\mathrm{ft}$ emitter spacing (T-Tape Systems Intl., San Diego, Calif.)] was installed about 2 inches below the soil surface and 4 $\mathrm{cm}$ from bed centers. Planting beds were covered with clear polyethylene film (1.2 mil thick). Solarization was ended by painting the clear polyethylene film with white latex paint using a minimum of three coats to minimize transmission of long-wave radiation through the film. The fumigants $\mathrm{MBr}$ + Pic and 1,3-D + Pic were injected between 3 and 7 weeks prior to tomato transplanting, using a three-knife rig that delivered the fumigants 10 inches deep. Knives were spaced 12 inches apart. Beds within the nonfumigated control plots were formed the same day as the fumigated plots. To facilitate tomato transplanting, solarized and nontreated plots were sprayed $7 \mathrm{~d}$ before transplanting with paraquat $(4.5$ $\mathrm{lb} / \mathrm{acre}$ ) to reduce existing weed cover (primarily purple nutsedge).
The fall tomato crops were established by transplanting 6-week-old 'Solimar' plants $2 \mathrm{ft}$ apart into the beds on 17 Sept. 1998, 13 Sept. 1999, 5 Sept. 2000, and 11 Sept. 2001. All plants received imidacloprid $(0.35$ $\mathrm{lb} / \mathrm{acre}$ as a flowable formulation) in the transplant water to control silverleaf whitefly (Bemisia argentifolii), thereby reducing the incidence of viruses early in the season. Plants were sprayed weekly with mancozeb (1.4 lb/acre as a dry flowable formulation) to protect against foliar diseases, and endosulfan and spinosad at 0.75 and $0.85 \mathrm{lb} / \mathrm{acre}$, respectively, were applied as needed to control insects. Subsurface irrigation was applied during the summer solarization period to maintain good bed moisture and maximize soil heating. After the tomato crop was established, both subsurface and drip irrigation were utilized to maintain the soil at field capacity. Depending upon the growth tomato stage, $\mathrm{N}$ and $\mathrm{K}$ were applied daily through the drip irrigation, beginning at 1 week after transplanting, with rates ranging from $\mathrm{N}$ at 1.0 to 2.4 $\mathrm{lb} / \mathrm{acre}$, and $\mathrm{K}$ at 0.8 to $1.9 \mathrm{lb} / \mathrm{acre}$ (Maynard et al., 2003).

At the end of each tomato season, plots were sprayed with a foliar application of paraquat at $1.25 \mathrm{lb} /$ acre using an eight-nozzle boom sprayer to eliminate all vegetation. A second application of paraquat at the same rate was made 2 weeks before planting cucumbers in the spring. Slicer ' $\mathrm{Com}$ petitor' cucumbers were direct-seeded the second week of February of each year on mulched beds with plant holes spaced $2 \mathrm{ft}$ apart. Three cucumber seeds per hole were planted and thinned to one plant per hole. The drip irrigation system was used to supply water and fertilizer ( $\mathrm{N}$ at $1.5 \mathrm{lb} /$ acre) to the cucumber plants on a daily basis. Fungicide (mancozeb as a dry flowable at $1.5 \mathrm{lb} /$ acre) was applied weekly and insecticides (endosulfan and spinosad at 0.75 and $0.85 \mathrm{lb} /$ acre, respectively) were applied as needed. In addition to drip, subsurface irrigation was supplied as needed.

Cucumber plant vigor was assessed at 10,7, and 9 weeks after planting in the 1999, 2000, and 2001 spring seasons by visually using a percentage scale where $100 \%$ represented optimum plant vigor and $0 \%$ indicated plant death. No vigor ratings were recorded in 2002. Weed populations in cucumber plots were determined at 9 ,
10,7 , and 14 weeks after planting by counting the total number of shoots emerged on bed-tops. Marketable cucumbers were harvested 8 to 10 times starting in the second week of April of each season. Soil samples for nematode identification and enumeration were collected at 14 weeks after planting with a 1 -inch-wide probe inserted 8 inches into the soil within the root zone of 8 to 10 plants per plot at the last cucumber harvest. Nematodes were separated from $100 \mathrm{~cm}^{3}$ of soil using a standard sieving and centrifugation procedure (Jenkins, 1964). The severity of rootknot nematode (Meloidogynespp.) gall formation on the roots of five cucumber plants per plot was evaluated at 14 weeks after planting by using a 0 to 10 rating scale where 0 represented no galls present and 10 indicated severely galled plants (Zeck, 1971).

Data were examined with analysis of variance (ANOVA) $(P=0.05)$. Weed and nematode count data were transformed before ANOVA by using a $\log _{10}+1$ transformation to stabilize variances. Also, tomato plant vigor values were normalized with square root arcsin transformation. Treatment means were separated using Duncan's multiple range test at the 5\% significance level (version 8; SAS Institute, Inc., Cary, N.C.).

\section{Results and discussion}

NutSEDge DENSITy. There were significant season by treatment interactions for this variable; thus, each year will be discussed separately. In 1999 and 2000 , the nontreated control had the highest densities, with 33 and 282 plants $/ \mathrm{m}^{2}$, respectively, whereas there were no differences among the remaining treatments, which had weed densities ranging from 3 to 7 and 15 to 38 plants $/ \mathrm{m}^{2}$ during both seasons (Table 1). During 2001, the $\mathrm{MBr}+\mathrm{Pic}$ and napropamide followed by solarization plots had the highest nutsedge control $\left(\leq 6\right.$ plants $\left./ \mathrm{m}^{2}\right)$, while the density in the pebulate + napropamide followed by $1,3-\mathrm{D}+$ Pic plots was intermediate between the nontreated control and the other two treatments. In 2002, napropamide followed by solarization reduced the nutsedge population to approximately one-third of that of the nontreated control, and it was at least as effective as the chemical alternatives.

In three of four seasons, doublecropped cucumber plots benefited 
from the application of the chemical and nonchemical programs for tomato, as reflected by the reduced nutsedge densities during the season following tomato. This finding suggested that the time between tomato fumigation and determining nutsedge densities in double-cropped cucumber, which was between 8 and 9 months for solely chemically fumigated and solarized plots, respectively, was not enough to increase nutsedge populations to the nontreated control levels during the first 3 years of the study. However, during the fourth year there was no lasting nutsedge control benefit from fumigations compared to the control. Moreover, the combination of solarization partnered with napropamide proved to be as effective as $\mathrm{MBr}+\mathrm{Pic}$ and pebulate + napropamide followed by $1,3-\mathrm{D}+$ Pic in controlling nutsedge in double cropped-cucumber.

Nematode ROOT GALLING AND POPUlATIONS. As for nutsedge, each season will be discussed separately because of the significant season by treatment interactions for both root-knot nematode root galling and nematode populations. For root galling, only the 1999 and 2000 seasons showed significant treatment effects (Table 1). During 1999, there was no root galling difference between $\mathrm{MBr}$ + Pic and pebulate + napropamide followed by 1,3-D + Pic treatments. The napropamide followed by solarization plots failed to reduce rootknot nematode-induced galling, with infection levels similar to those of the nontreated control. In contrast, during 2000 all treated plots performed better than the nontreated control, with no differences among all three options, although root galling levels were not commercially acceptable (galling index $\geq 4.4$ ), which reflects the severity of root-knot nematode infection in the experimental site. This situation was aggravated during the 2002 season, where there were no differences among all four treatments and the galling indexes were $\geq 6.6$. These data indicated that, in contrast with nutsedge densities, there was a weak negative effect of tomato fumigants in double-cropped cucumber, with root galling indexes consistently increasing throughout the cucumber seasons.

The nematode genera Meloidogyne, Tylenchorbynchus (stunt nematode), Criconemoides(ring nematode), and Belonolaimus (sting nematode) were present in the study from 2000 to 2002 (Table 2). During the 2000 season, root-knot nematode, stunt nematode, and ring nematode populations in double-cropped cucumber were significantly influenced by the fumigant application in tomato, whereas there was no effect on sting nematode counts. For root-knot nematode, there was no difference between $\mathrm{MBr}+\mathrm{Pic}$ and pebulate + napropamide followed by 1,3-D + Pic, while solarization performed equal to the nontreated control (339 and 332 juveniles/100 mL soil, respectively). All treated plots had lower stunt and ring nematode populations than the nontreated control. In 2001 and 2002, root-knot nematode counts ranged between 40 and 156 , and between 54 and 175 juveniles/100 $\mathrm{mL}$ soil, respectively, with none of the treatments having an impact on the population. However, stunt, ring, and sting nematodes were affected by the fumigants during the 2001 season.
Both napropamide followed by solarization, and pebulate + napropamide followed by 1,3-D + Pic were equally effective as $\mathrm{MBr}+\mathrm{Pic}$ in controlling these three nematode genera (Table 2). In contrast, only sting nematode was influenced by the tomato fumigants during the last cucumber season, where the napropamide followed by solarization treatment failed to reach the $\mathrm{MBr}$ + Pic control level.

Based on these results, it appeared that in the case of stunt nematode and ring nematode, there was a long-term beneficial effect of the tomato-applied chemical and nonchemical treatments, which reflected as reduced populations during in 2000 and 2001. However, this benefit disappeared in 2002. For root-knot nematode, the population evolution during all three sampled seasons is consistent with the root galling indexes discussed previously.

Cucumber VIGOR AND YIELD. During the 1999 season, plant vigor ratings for $\mathrm{MBr}+\mathrm{Pic}$ were higher $(82 \%)$ than for the napropamide followed by solarization $(68 \%)$ and the nontreated (71\%) plots, but comparable to that for pebulate + napropamide followed by $1,3-\mathrm{D}+$ Pic (Table 3). Marketable cucumber yield followed this same pattern, with the napropamide followed by solarization treatment and the nontreated control having about $49 \%$ and $39 \%$ yield reductions, respectively, in comparison with $\mathrm{MBr}+\mathrm{Pic}$, whereas there was no difference between $\mathrm{MBr}$ + Pic and pebulate + napropamide followed by 1,3-D + Pic. The following season, the solarized plots had the same vigor and marketable yield as $\mathrm{MBr}+\mathrm{Pic}$ and pebulate + napropamide followed by 1,3-D + Pic, which were higher

Table 1. Effects of methyl bromide alternatives applied in previous tomato seasons on nutsedge densities (yellow nutsedge + purple nutsedge) and root-knot nematode galling index in double-cropped cucumber during 1999, 2000, 2001, and 2002 spring seasons in Bradenton, Fla.

\begin{tabular}{|c|c|c|c|c|c|c|c|c|c|c|}
\hline \multirow[b]{2}{*}{ Fumigants $^{\mathrm{z}}$} & \multirow{2}{*}{$\begin{array}{c}\text { Rate } \\
\text { per acre }\end{array}$} & \multirow[b]{2}{*}{ Herbicides } & \multirow{2}{*}{$\begin{array}{l}\text { Rate } \\
\text { per acre }\end{array}$} & \multicolumn{4}{|c|}{ Nutsedge density ${ }^{\mathrm{x}}$ (plants $/ \mathrm{m}^{2}$ ) } & \multicolumn{3}{|c|}{ Root galling index ${ }^{w}$} \\
\hline & & & & 1999 & 2000 & 2001 & 2002 & 1999 & 2000 & 2002 \\
\hline Nontreated & --- & --- & --- & $33 \mathrm{a}$ & $282 \mathrm{a}$ & $87 \mathrm{a}$ & $37 \mathrm{a}$ & $6.0 \mathrm{a}$ & $9.0 \mathrm{a}$ & 8.0 \\
\hline $1,3-\mathrm{D}+\mathrm{Pic}$ & $40 \mathrm{gal}$ & $\begin{array}{l}\text { Pebulate }+ \\
\text { napropamide }\end{array}$ & $4+2 \mathrm{lb}$ & $6 \mathrm{~b}$ & $38 \mathrm{~b}$ & $28 \mathrm{~b}$ & $20 \mathrm{ab}$ & $3.8 \mathrm{ab}$ & $4.5 \mathrm{~b}$ & 7.0 \\
\hline Solarization & --- & Napropamide & $2 \mathrm{lb}$ & $3 \mathrm{~b}$ & $15 \mathrm{~b}$ & $6 \mathrm{c}$ & $13 \mathrm{~b}$ & $6.2 \mathrm{a}$ & $5.6 \mathrm{~b}$ & 6.6 \\
\hline
\end{tabular}

${ }^{2} \mathrm{MBr}=$ methyl bromide; Pic $=$ chloropicrin; $1,3-\mathrm{D}=1,3$-dichloropropene.

y plant $/ \mathrm{m}^{2}=0.0929 \mathrm{plant} / \mathrm{ft}^{2} ; 1 \mathrm{lb} /$ acre $=1.1209 \mathrm{~kg} \cdot \mathrm{ha} \mathrm{H}^{-1} ; \mathrm{l} \mathrm{gal} /$ acre $=9.3540 \mathrm{~L} \cdot \mathrm{ha}^{-1}$

${ }^{x}$ Nutsedge density obtained at $9,10,7$, and 14 weeks after planting in $1999,2000,2001$, and 2002 spring seasons, respectively. Data transformed with log +1 prior to analysis of variance (ANOVA) and treatment means separated with Duncan's multiple range test $(P \leq 0.05)$.

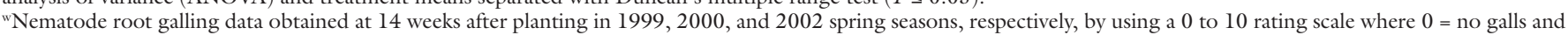
$10=$ severely galled plants. Data transformed with $\log _{10}+1$ prior to ANOVA and treatment means separated with Duncan's multiple range test $(P \leq 0.05)$.

ss, * Nonsignificant or significant at $P=0.05$, respectively. 
Table 2. Effects of methyl bromide alternatives applied in previous tomato seasons on root-knot nematode, stunt nematode, ring nematode, and sting nematode populations in double-cropped cucumber during 2000, 2001, and 2002 spring seasons in Bradenton, Fla.

\begin{tabular}{|c|c|c|c|c|c|c|c|}
\hline \multirow[b]{2}{*}{ Fumigants $^{\mathrm{z}}$} & \multirow{2}{*}{$\begin{array}{c}\text { Rate } \\
\text { per acre }\end{array}$} & \multirow[b]{2}{*}{ Herbicides } & \multirow{2}{*}{$\begin{array}{c}\text { Rate } \\
\text { per acre }\end{array}$} & \multicolumn{4}{|c|}{ Nematode population $^{\mathrm{x}}($ no./mL) } \\
\hline & & & & Root-knot & Stunt & Ring & Sting \\
\hline & & & & \multicolumn{4}{|c|}{2000} \\
\hline Nontreated & --- & --- & --- & $332 \mathrm{a}$ & $35 \mathrm{a}$ & $11 \mathrm{a}$ & 10 \\
\hline $\mathrm{MBr}+\mathrm{Pic}$ & $350 \mathrm{lb}$ & --- & --- & $156 \mathrm{~b}$ & $7 \mathrm{~b}$ & $0 \mathrm{~b}$ & 0 \\
\hline $1,3-\mathrm{D}+\mathrm{Pic}$ & $40 \mathrm{gal}$ & $\begin{array}{l}\text { Pebulate }+ \\
\text { napropamide }\end{array}$ & $4+2 \mathrm{lb}$ & $164 \mathrm{~b}$ & $4 \mathrm{~b}$ & $0 \mathrm{~b}$ & 0 \\
\hline Solarization & --- & Napropamide & $2 \mathrm{lb}$ & 339 a & $7 \mathrm{~b}$ & $0 \mathrm{~b}$ & 0 \\
\hline \multirow[t]{2}{*}{ Significance } & & & & * & * & * & NS \\
\hline & & & & \multicolumn{4}{|c|}{2001} \\
\hline Nontreated & --- & --- & --- & 40 & $32 \mathrm{a}$ & $117 \mathrm{a}$ & $56 \mathrm{a}$ \\
\hline $\mathrm{MBr}+\mathrm{Pic}$ & $350 \mathrm{lb}$ & --- & --- & 59 & $\mathrm{lb}$ & $0 \mathrm{~b}$ & $1 \mathrm{c}$ \\
\hline $1,3-\mathrm{D}+\mathrm{Pic}$ & $40 \mathrm{gal}$ & $\begin{array}{l}\text { Pebulate }+ \\
\text { napropamide }\end{array}$ & $4+2 \mathrm{lb}$ & 82 & $14 \mathrm{ab}$ & $0 \mathrm{~b}$ & $3 \mathrm{bc}$ \\
\hline Solarization & --- & Napropamide & $2 \mathrm{lb}$ & 156 & $11 \mathrm{ab}$ & $7 \mathrm{~b}$ & $19 \mathrm{~b}$ \\
\hline \multirow[t]{2}{*}{ Significance } & & & & NS & * & * & * \\
\hline & & & & \multicolumn{4}{|c|}{2002} \\
\hline Nontreated & --- & --- & --- & 54 & 0 & 82 & $16 \mathrm{a}$ \\
\hline $\mathrm{MBr}+\mathrm{Pic}$ & $350 \mathrm{lb}$ & --- & --- & 175 & 2 & 12 & $1 \mathrm{c}$ \\
\hline $1,3-\mathrm{D}+\mathrm{Pic}$ & $40 \mathrm{gal}$ & Pebulate + & $4+2 \mathrm{lb}$ & 78 & 1 & 1 & $0 \mathrm{c}$ \\
\hline Solarization & --- & $\begin{array}{l}\text { Napropamide } \\
\text { napropamide }\end{array}$ & $2 \mathrm{lb}$ & 169 & 2 & 2 & $8 \mathrm{~b}$ \\
\hline Significance & & & & NS & NS & NS & * \\
\hline
\end{tabular}

Table 3. Effects of methyl bromide alternatives applied in previous tomato seasons on double-cropped cucumber plant vigor and marketable yield during 1999, 2000, 2001, and 2002 spring seasons in Bradenton, Fla.

\begin{tabular}{|c|c|c|c|c|c|c|c|c|c|c|}
\hline \multirow[b]{2}{*}{ Fumigants $^{\mathrm{z}}$} & \multirow{2}{*}{$\begin{array}{c}\text { Rate } \\
\text { per acre }\end{array}$} & \multirow[b]{2}{*}{ Herbicides } & \multirow{2}{*}{$\begin{array}{c}\text { Rate } \\
\text { per acre }\end{array}$} & \multicolumn{3}{|c|}{ Plant vigor ${ }^{\mathrm{x}}(\%)$} & \multicolumn{4}{|c|}{ Marketable yield $\left(\mathrm{t} \cdot \mathrm{ha}^{-1}\right)$} \\
\hline & & & & 1999 & 2000 & 2001 & 1999 & 2000 & 2001 & 2002 \\
\hline Nontreated & --- & --- & --- & $71 \mathrm{~b}$ & $52 \mathrm{~b}$ & $31 \mathrm{~b}$ & $15.1 \mathrm{~b}$ & $5.7 \mathrm{~b}$ & $5.0 \mathrm{~b}$ & $4.7 \mathrm{~b}$ \\
\hline 1,3-D + Pic & $40 \mathrm{gal}$ & $\begin{array}{l}\text { Pebulate + } \\
\text { napropamide }\end{array}$ & $4+2 \mathrm{lb}$ & $78 \mathrm{ab}$ & $77 \mathrm{a}$ & $82 \mathrm{a}$ & $19.8 \mathrm{ab}$ & $22.2 \mathrm{a}$ & $17.0 \mathrm{a}$ & $11.7 \mathrm{ab}$ \\
\hline $\begin{array}{l}\text { Solarization } \\
\text { Significance }\end{array}$ & --- & Napropamide & $2 \mathrm{lb}$ & $\begin{array}{c}68 \mathrm{~b} \\
*\end{array}$ & $\begin{array}{c}83 \mathrm{a} \\
*\end{array}$ & $\begin{array}{c}38 \mathrm{~b} \\
*\end{array}$ & $\begin{array}{c}12.7 \mathrm{~b} \\
*\end{array}$ & $\begin{array}{c}21.6 \mathrm{a} \\
*\end{array}$ & $\begin{array}{c}9.6 \mathrm{~b} \\
*\end{array}$ & $\begin{array}{c}15.5 \mathrm{a} \\
*\end{array}$ \\
\hline
\end{tabular}

${ }^{\mathrm{z}} \mathrm{MBr}=$ methyl bromide; Pic = chloropicrin; 1,3-D = 1,3-dichloropropene.

$1 \mathrm{lb} /$ acre $=1.1209 \mathrm{~kg} \cdot \mathrm{ha}^{-1} ; \mathrm{l} \mathrm{gal} / \mathrm{acre}=9.3540 \mathrm{~L} \cdot \mathrm{ha}^{-1} ; \mathrm{l} \mathrm{t} \cdot \mathrm{ha}^{-1}=0.4461 \mathrm{ton} /$ acre.

'Plant vigor obtained at 10,7, and 9 weeks after planting in 1999,2000 , and 2001 spring seasons, respectively, by using a percentage scale where $100 \%=$ optimum plant vigor and $0 \%=$ plant death. Data transformed with square root arcsin prior to analysis of variance and treatment means separated with Duncan's multiple range test $(P \leq 0.05)$.

"Significant at $P=0.05$

than the nontreated control (Table 3 ). However, in the 2001 trial, the napropamide followed by solarization treatment had approximately one-half of the plant vigor and marketable yield of $\mathrm{MBr}+\mathrm{Pic}$. Interestingly, during the next season (2002) double-cropped cucumber yield for the solarized plots again equaled those for $\mathrm{MBr}+\mathrm{Pic}$, and pebulate + napropamide followed by $1,3-\mathrm{D}+$ Pic.

Throughout the four cucumber seasons, the combination of pebulate + napropamide followed by 1,3-D +
Pic proved to produce consistently equal marketable yields as those for $\mathrm{MBr}+\mathrm{Pic}$. Both treatments effectively controlled nutsedge and nematodes during all four seasons. Although pebulate is not currently registered, these results demonstrate that an effective weed management program for double-cropped cucumber after tomato could be obtained by combining preplant incorporated herbicides and the fumigant 1,3-D + Pic. Since nematode control is directly linked to the fumigant use in that management program, it is unlikely to expect significant nematode population changes due to variations on herbicide use. On the other hand, the napropamide followed by soil solarization plots were only comparable to $\mathrm{MBr}+\mathrm{Pic}$ in two of the seasons. This finding indicated that solarization could be a potential tool for designing integrated soilborne pest management programs with $\mathrm{MBr}$ alternatives for mulched crops. However, nematode control needs to be improved to maximize the benefits of this methodology. 


\section{Literature cited}

Chase, C.A., T.R. Sinclair, and S.J. Locascio. 1999. Effects of soil temperature and tuber depth on Cyperus spp. control. Weed Sci. 47:467-472.

Chase, C.A., T.R. Sinclair, D.O. Chellemi, S.M. Olson, J. Rich, S.J. Locascio, J.P. Gilreath, and J.P. Jones. 1997a. Soil solarization as an alternative to methyl bromide in vegetable production. Proc. Southern Weed Sci. Soc. 50:82.

Chase, C.A., T.R. Sinclair, S.J. Locascio, J.P. Gilreath, J.P. Jones, and D.W. Dickson. 1997b. An evaluation of improved polyethylene films for cool-season soil solarization. Proc. Fla. State Hort. Soc. 110:326-329.

Chellemi, D.O., S.M. Olson, D.J. Mitchell, I. Secker, and R. McSorley. 1997. Adaptation of soil solarization to the integrated management of soilborne pests of tomato under humid conditions. Phytopathology $87: 250-258$

Gilreath, J.P., J.P. Jones, and A.J. Overman. 1994. Soil-borne pest control in mulched tomato with alternatives to methyl bromide. Proc. Fla. State Hort. Soc. 107: 156-159.

Gilreath, J.P., J.W. Noling, and B.M. Santos. 2004. Methyl bromide alternatives for pepper (Capsicum annumm) and cucumber (Cucumis sativus) rotations. Crop Protection 23:347-351.

Gilreath, J.P., J.W. Noling, P.R. Gilreath, and J.P. Jones. 1997. Field validation of 1,3-dichloropropene + chloropicrin and pebulate as an alternative to methyl bromide in tomato. Proc. Fla. State Hort. Soc. 110:273-276.
Jenkins, W.R. 1964. A rapid centrifugal-flotation technique for separating nematodes from soil. Plant Dis. Reptr. 48:692.

Jones, J.P., J.P. Gilreath, A.J. Overman, and J.W. Noling. 1995. Control of soilborne diseases of mulched tomato by fumigation. Proc. Fla. State Hort. Soc. 108:201-203.

Locascio, S.J., J.P. Gilreath, D.W. Dickson, T.A. Kucharek, J.P. Jones, and J.W. Noling. 1997. Fumigant alternatives to methyl bromide for polyethylene-mulched tomato. HortScience 32:1208-1211.

Maynard, D.N., G.J. Hochmuth, S.M. Olson, C.S. Vavrina, W.M. Stall, T.A. Kucharek, S.E. Webb, T.G. Taylor, and S.A. Smith. 2003. Tomato production in Florida, p. 259-270. In: S.M. Olson and D.N. Maynard (eds.). Vegetable production guide for Florida, 2002-2003. IFAS Publ., Univ. of Florida.

Overman, A.J. and F.G. Martin. 1978. A survey of soil and crop management practices in the Florida tomato industry. Proc. Fla. State Hort. Soc. 91:294-297.

U.S. Environmental Protection Agency. 1999. Protection of stratospheric ozone: Incorporation of Montreal protocol adjustment for a 1999 interim reduction in Class I, Group VI controlled substances. Federal Register 64:29240-29245.

Zeck, W.M. 1971. A rating scheme for field evaluation of root-knot nematode infestations. Pflanzenschutz-Nachrichten 24:141-144. 